\title{
BENZENE EXPOSURE FROM THE BP REFINERY FLARING INCIDENT ALTERS HEMATOLOGICAL AND HEPATIC FUNCTIONS AMONG SMOKING SUBJECTS
}

\author{
MARK A. D'ANDREA and G. KESAVA REDDY \\ University Cancer and Diagnostic Centers, Houston, USA
}

\begin{abstract}
Objectives: To evaluate the health effects of benzene exposure among smoking subjects from a prolonged flaring incident that occurred at the British Petroleum (BP) refinery in Texas City, USA. Material and Methods: The study included smoking subjects who had been exposed and unexposed to the benzene release. Using medical charts, clinical data including white blood cell (WBC) counts, platelet counts, hemoglobin, hematocrit, blood urea nitrogen (BUN), creatinine, alkaline phosphatase (ALP), aspartate aminotransferase (AST), and alanine aminotransferase (ALT) in the case of smoking subjects exposed to benzene was reviewed and analyzed. Results: A total of 791 tobacco smoking subjects (benzene-exposed: $\mathrm{N}=733$, unexposed: $\mathrm{N}=58$ ) were included. Benzene-exposed subjects had significantly higher levels of $\mathrm{WBC}\left(\times 10^{3} / \mu \mathrm{l}\right)$ counts $(8 \pm 2.1$ vs. $7.5 \pm 1.6, \mathrm{p}=0.003)$ and platelet $\left(\times 10^{3} / \mu \mathrm{l}\right)$ counts $(263.7 \pm 69.7$ vs. $222.9 \pm 44.3$, $p=0.000)$ as compared with the unexposed subjects. The mean hemoglobin, hematocrit, BUN, and creatinine levels did not differ significantly between the benzene-exposed and -unexposed smoking subjects. Serum levels of ALP (IU/l) was significantly elevated in the benzene-exposed subjects compared with the unexposed subjects $(84.5 \pm 16.9$ vs. $73.8 \pm 15.9$, $\mathrm{p}=0.002$ ). Similarly, benzene-exposed subjects had significantly higher levels of AST and ALT as compared with those unexposed subjects. Conclusions: Despite a smoking history, residents exposed to benzene from the prolonged BP flaring incident experienced significant alterations in hematological and hepatic functions indicating their vulnerability to the risk of developing hepatic or blood related disorders. Int J Occup Med Environ Health 2017;30(6):849-860
\end{abstract}

Key words:

Benzene poisoning, Blood disorders, Hematological toxicity, Hepatotoxicity, Petroleum refinery, Tobacco smoking

\section{INTRODUCTION}

Benzene, a chief constituent of crude oil and gasoline, is an important volatile organic chemical produced at high levels in both the petroleum and manufacturing industries. Benzene is used as the primary starting material to produce a variety of commercial products including detergents, drugs, dyes, synthetic fibers, resins, pesticides, and plastics. Thus, petroleum and chemical manufacturing industries are the major sources for human exposure to benzene.
Benzene is also an intrinsic component of tobacco. Tobacco smokers have higher blood and urine levels of benzene than nonsmokers [1]. Benzene is a highly volatile organic compound and may contaminate the surrounding environment rapidly. Natural processes such as volcanoes and forest fires and human activities related to chemical manufacturing industries play a critical role in contaminating the environment. Therefore, communities located near these sources are at a higher risk of being exposed to benzene. 
Benzene exposure is associated with multiple adverse health effects in both adults and children. Therefore, benzene poisoning is of particular concern because current evidence suggests that it may result in significant toxicity. Benzene exposure may affect the bone marrow leading to anemia and the development of cancer. Exposure to benzene may cause leukemia, lymphoma, multiple myeloma, aplastic anemia, and other solid cancers [2-6].

In addition, benzene exposure is associated with a wide range of non-cancerous but adverse effects including alterations in pulmonary, central nervous system, hematological, hepatic, and renal functions [7-11]. Adverse respiratory effects of benzene include pulmonary edema, acute granular tracheitis, laryngitis, bronchitis, fibrosis, and massive hemorrhaging.

Although earlier studies have been reported regarding the adverse health effects of benzene exposure for humans [12,13], the pathology of benzene-induced toxicity is not completely known. Multiple possible mechanisms have been postulated about the toxicity of benzene exposure. It is believed that the toxic effects of benzene may arise from its metabolism, which proceeds along several lines leading to the generation of several benzene metabolites such as benzoquinone, hydroquinone, muconaldehydes, catechol, and phenol [14].

In addition, benzene exposure is associated with DNA damage, oxidative stress, disruption of the cell cycle, and programmed cell death leading to the development of adverse health effects [15-17]. Moreover, benzene may interfere with innate, humoral and cellular immunity and disrupts the immune function contributing to its toxicity $[18,19]$.

A flaring disaster that occurred at a British Petroleum (BP) refinery plant resulted in a huge amount of toxic chemical release into the skies of Texas City, USA [20,21]. Consequently, over $500000 \mathrm{lb}$ of toxic chemicals, including over $17000 \mathrm{lb}$ of benzene were released threatening the health of the residents living in the surrounding communities of the BP refin- ery facility [20-22]. The local County District Clerk's Office estimated that over 50000 people were presumed to be affected as a result of the BP refinery flaring incident.

To assess the potential health consequences of this ambient benzene exposure that resulted from the BP flaring incident, a series of studies are being conducted examining the hematological and hepatic functions in affected subjects. The initial findings of these studies have revealed that benzene exposure has significantly altered the hematological and hepatic indices in the case of the exposed subjects as compared with the unexposed subjects [23-27]. In addition, those persons exposed to benzene had a range of illness symptoms and an altered profile of urinary phenol indicating their vulnerability to increased health complications [28]. Since tobacco and cigarette smoke is also a wellknown source of benzene exposure [29], tobacco smoking is considered to be a potential confounder in determining the health effects of benzene. Therefore, in this study, we have included only tobacco smoking subjects who had been exposed to benzene and assessed their hematological and hepatic functions and compared them with smoking subjects who had not been exposed to benzene.

\section{MATERIAL AND METHODS Subjects}

An Institutional Review Board reviewed the protocol and approved this retrospective study. The subjects' selection and the procedures used for the clinical and laboratory evaluations had been reported previously in detail [23-28]. Briefly, between June 2010 and October 2012 subjects underwent clinical as well as laboratory evaluations and their data is included in the study. Specifically, subjects exposed to benzene from residential areas in and surrounding Texas City, USA, were selected from the community (Figure 1). In particular, subjects included in this study were exposed to benzene for a prolonged period for up to 40 days from the BP refinery flaring disaster that had occurred on April 6, 2010 and lasted through May 16, 2010. Control 


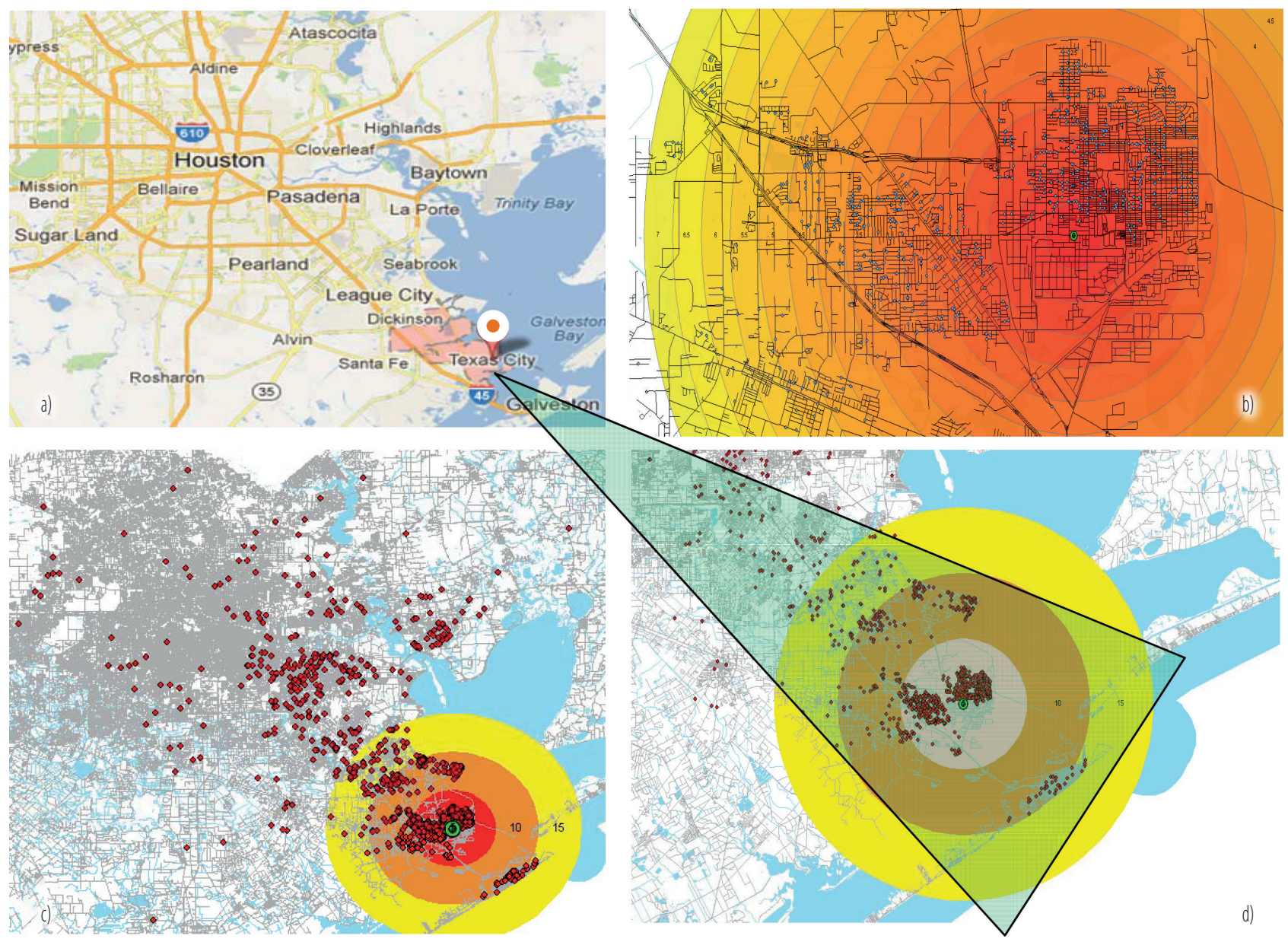

Reprinted and modified with permission from American Journal of Disaster Medicine, Vol. 8, No. 3: 169-179 [23].

a) Location of Texas City, USA.

b) Depicted intensity of benzene exposure from BP incident surrounding neighborhoods of Texas City, USA. The red, orange, and yellow colors depict the higher (red) to reduced (orange) to low (yellow) intensity of benzene exposure.

c) Scattered dots represent the location/address of the study participants who were exposed to benzene following the flaring incident at the BP refinery and surrounding areas.

d) A closer look at the area affected by the benzene exposure and the address of the study participants (scattered dots).

Fig. 1. Map showing the location of the disaster of BP refinery facility in the northern parts of the Texas City, USA

subjects who were unexposed to benzene were drawn from primary care clinics located approximately 30-50 miles away from the BP refinery plant [23-28]. Specifically, unexposed subjects to benzene were selected randomly by the primary care physician following their visit to the clinic for a routine wellness checkup.

Only subjects in either exposed or unexposed to benzene groups with a smoking history or who were smoking at that time were eligible for inclusion in this study. Using their medical records, demographic and clinical laboratory data was collected and analyzed. The ethical principles of the Declaration of Helsinki were followed throughout this study. To comply with the Health Insurance Portability and Accountability Act (HIPAA), confidentiality of information was secured by utilizing text encryption, password protection and limited personnel involvement. 


\section{Data analysis}

Clinical data was collected from the medical records of the benzene-exposed and -unexposed smoking subjects and subjected to statistical analysis. Hematological function was assessed by evaluating white blood cell (WBC) counts, platelet counts, hemoglobin, hematocrit, and blood urea nitrogen (BUN). Alkaline phosphatase (ALP), aspartate amino transferase (AST), and alanine amino transferase (ALT) levels were assessed as the measure of hepatic function. Renal function was evaluated by measuring serum creatinine. An outside accredited laboratory facility (LabCorp, Laboratory Corporation of America, Houston, USA) was used for clinical laboratory tests for both the benzene-exposed and -unexposed subjects.

\section{Statistics}

The assessment of the data on demographics and clinical parameters included means and standard deviations for each group. Variables included were age, gender, WBC, platelets, hemoglobin, hematocrit, creatinine, BUN, ALP, AST, and ALT. Simple Student's t-test was used for comparing the differences between the benzene-exposed and -unexposed groups. The significance level was predetermined at $\alpha$ level of 0.05 .

\section{RESULTS}

This study included a total of 791 tobacco smoking subjects. Out of the 791 smoking subjects, 58 were unexposed and 733 were exposed to benzene. The demographics of the subjects are shown in the Table 1. The mean age of the unexposed and benzene-exposed subjects was 41 years old and 42.1 years old, respectively. Out of the 58 unexposed subjects, 37 (64\%) were male and $21(36 \%)$ were female. There were $465(63 \%)$ male and $268(37 \%)$ female subjects in the benzene-exposed group. The median time from the time of disaster till the time of the laboratory testing for the exposed group was 145 (range: 77-439) days.
The differences in hematologic and hepatic markers between the unexposed and exposed tobacco smoking subjects to benzene were presented in the Table 2. The mean WBC counts $\left(\times 10^{3} / \mu 1\right)$ were significantly higher in the benzeneexposed subjects as compared with those of the unexposed subjects ( $8 \pm 2.1$ vs. $7.5 \pm 1.6, p=0.003)$. Similarly, the mean platelet counts $\left(\times 10^{3} / \mu \mathrm{l}\right)$ in the benzene-exposed group were significantly elevated as compared with the unexposed group (263.7 \pm 69.7 vs. $222.9 \pm 44.3, \mathrm{p}=0.000)$. The mean hemoglobin (g/dl), hematocrit (\%), BUN (mg/dl), and creatinine $(\mathrm{mg} / \mathrm{dl})$ levels did not differ significantly between the benzene-exposed and unexposed subjects.

The mean serum ALP (IU/l) levels were found to be increased for subjects exposed to benzene as compared with the unexposed subjects $(84.5 \pm 16.9$ vs. $73.8 \pm 15.9, p=0.002)$. Similarly, the mean serum AST (IU/l) levels were significantly higher in the benzene-exposed subjects as compared with the unexposed subjects $(26.8 \pm 6.2$ vs. 21.6 $\pm 5.1, \mathrm{p}=0.044)$. The mean serum ALT (IU/l) levels were increased significantly in the benzene-exposed group as compared with the unexposed group (30.1 \pm 12.2 vs. $24.4 \pm 9.2, p=0.015)$.

The results presented in the Table 3 represent the differences in hematologic and hepatic markers between the benzene-exposed and -unexposed smoking subjects according to their gender. The mean WBC counts $\left(\times 10^{3} / \mu 1\right)$ were statistically similar between the benzene-exposed and unexposed male subjects $(8 \pm 2.3$ vs. $7.8 \pm 1.5, \mathrm{p}=0.35)$. However, the mean WBC counts $\left(\times 10^{3} / \mu \mathrm{l}\right)$ were significantly higher for female subjects who were exposed to benzene as compared with those unexposed female subjects $(8 \pm 2.2$ vs. $7.2 \pm 1.2, p=0.001)$. The mean platelet counts $\left(\times 10^{3} / \mu \mathrm{l}\right)$ for male $(247.4 \pm 45.7$ vs. $217 \pm 34.4$, $\mathrm{p}=0.0036)$ and female $(286.4 \pm 73.6$ vs. $233.8 \pm 58.3$, $\mathrm{p}=0.0008$ ) subjects exposed to benzene were significantly elevated as compared with the unexposed group. Similarly, the mean serum ALP levels (IU/l) were significantly elevated for male $(81.4 \pm 23.7$ vs. $71.9 \pm 17.7, p=0.008)$ and female $(83.5 \pm 16.7$ vs. $72.7 \pm 15.9, p=0.0287)$ subjects in 
Table 1. Demographic characteristics of the study group - smoking subjects, exposed and unexposed to benzene

\begin{tabular}{|c|c|c|}
\hline \multirow{2}{*}{ Variable } & \multicolumn{2}{|c|}{$\begin{array}{c}\text { Respondents } \\
(\mathrm{N}=791)\end{array}$} \\
\hline & unexposed & exposed \\
\hline Age [years] (M (min.-max)) & $41(21-62)$ & $42(19-69)$ \\
\hline \multicolumn{3}{|l|}{ Gender $[\mathrm{n}(\%)]$} \\
\hline male & $37(64)$ & $465(63)$ \\
\hline female & $21(36)$ & $268(37)$ \\
\hline total & $58(100)$ & $733(100)$ \\
\hline
\end{tabular}

M - mean; min. - minimal value; max - maximal value.

Table 2. Hematological and hepatic indices among smoking subjects, unexposed and exposed to benzene

\begin{tabular}{|c|c|c|c|}
\hline \multirow{2}{*}{ Variable } & \multicolumn{2}{|c|}{$\begin{array}{l}\text { Respondents } \\
(\mathrm{N}=791)\end{array}$} & \multirow{2}{*}{$\mathrm{p}$} \\
\hline & $\begin{array}{l}\text { unexposed } \\
(\mathrm{N}=58)\end{array}$ & $\begin{array}{c}\text { exposed } \\
(\mathrm{N}=733)\end{array}$ & \\
\hline White blood cells $(\mathrm{WBC})\left[\times 10^{3} / \mu \mathrm{l}\right](\mathrm{M} \pm \mathrm{SD})$ & $7.5 \pm 1.6$ & $8.0 \pm 2.1$ & $0.003^{* *}$ \\
\hline Platelets $\left[\times 10^{3} / \mu \mathrm{l}\right](\mathrm{M} \pm \mathrm{SD})$ & $222.9 \pm 44.3$ & $263.7 \pm 69.7$ & $0.000^{* *}$ \\
\hline Hemoglobin $[\mathrm{g} / \mathrm{dl}](\mathrm{M} \pm \mathrm{SD})$ & $15.0 \pm 1.6$ & $14.8 \pm 2.6$ & $0.3897^{\mathrm{a}}$ \\
\hline Hematocrit [\%] (M $\pm \mathrm{SD})$ & $44.2 \pm 4.8$ & $43.5 \pm 4.5$ & $0.1437^{\mathrm{a}}$ \\
\hline Blood urea nitrogen $(\mathrm{BUN})[\mathrm{mg} / \mathrm{dl}](\mathrm{M} \pm \mathrm{SD})$ & $13.6 \pm 3.6$ & $13.1 \pm 3.2$ & $0.2748^{\mathrm{a}}$ \\
\hline Creatinine $[\mathrm{mg} / \mathrm{dl}](\mathrm{M} \pm \mathrm{SD})$ & $0.8 \pm 0.2$ & $0.8 \pm 0.2$ & $0.223^{\mathrm{a}}$ \\
\hline Alkaline phosphatase (ALP) [IU/l] $(\mathrm{M} \pm \mathrm{SD})$ & $73.8 \pm 15.9$ & $84.5 \pm 16.9$ & $0.002^{* *}$ \\
\hline Aspartate amino transferase (AST) $[\mathrm{IU} / \mathrm{l}](\mathrm{M} \pm \mathrm{SD})$ & $21.6 \pm 5.1$ & $26.8 \pm 6.2$ & $0.0441^{*}$ \\
\hline Alanine amino transferase (ALT) [IU/l] $(\mathrm{M} \pm \mathrm{SD})$ & $24.4 \pm 9.2$ & $30.1 \pm 12.2$ & $0.0149^{*}$ \\
\hline
\end{tabular}

$\mathrm{M}$ - mean; SD - standard deviation.

$* \mathrm{p}=0.05 ; * \mathrm{p}=0.001$.

${ }^{\text {a }}$ Did not reach statistical significance.

the benzene-exposed group as compared with the unexposed group. Although benzene-exposed male subjects had significantly higher mean serum AST levels (IU/l) as compared with unexposed male subjects $(33.3 \pm 6.2$ vs. 21.9 $\pm 5.5, \mathrm{p}=0.0158$ ), no significant differences were observed between benzene-exposed and unexposed female subjects $(21.1 \pm 5.2$ vs. $18.6 \pm 4.9, p=0.129)$. Similarly, benzene-exposed male subjects had significantly higher mean serum ALT levels (IU/l) as compared with unexposed male subjects ( $37 \pm 7.8$ vs. $27.8 \pm 4.6, p=0.023$ ), no significant differences were observed between benzene-exposed and -unexposed female subjects $(23.4 \pm 7.9$ vs. $18.6 \pm 6$, $\mathrm{p}=0.133)$. The mean hemoglobin $(\mathrm{g} / \mathrm{dl})$, hematocrit $(\%)$, BUN (mg/dl), and creatinine (mg/dl) levels did not differ significantly in the male or female subjects between the benzene-exposed and -unexposed groups.

To assess if age had any significant impact on the health effects of benzene exposure among smoking subjects, the study participants were categorized into $<40$ years and $\geq 40$ years of age groups and the clinical findings were compared between the unexposed and benzeneexposed groups. The findings in the Table 4 show the 
Table 3. Hematological and hepatic indices among smoking subjects unexposed and exposed to benzene, according to gender

\begin{tabular}{|c|c|c|c|}
\hline \multirow[b]{2}{*}{ Variable and gender } & \multicolumn{2}{|c|}{$\begin{array}{l}\text { Respondents } \\
(\mathrm{N}=791)\end{array}$} & \multirow[b]{2}{*}{$\mathrm{p}$} \\
\hline & $\begin{array}{c}\text { unexposed } \\
\quad(\mathrm{N}=58 ; \\
37 \text { males, } 21 \text { females })\end{array}$ & $\begin{array}{c}\text { exposed } \\
(\mathrm{N}=733 ; \\
465 \text { males, } 268 \text { females })\end{array}$ & \\
\hline \multicolumn{4}{|l|}{$\mathrm{WBC}\left[\times 10^{3} / \mu \mathrm{l}\right](\mathrm{M} \pm \mathrm{SD})$} \\
\hline male & $7.8 \pm 1.5$ & $8.0 \pm 2.3$ & $0.3537^{\mathrm{a}}$ \\
\hline female & $7.2 \pm 1.2$ & $8.0 \pm 2.2$ & $0.0000^{* *}$ \\
\hline \multicolumn{4}{|l|}{ Platelets $\left[\times 10^{3} / \mu \mathrm{l}\right](\mathrm{M} \pm \mathrm{SD})$} \\
\hline male & $217.0 \pm 34.4$ & $247.4 \pm 45.7$ & $0.0036^{* *}$ \\
\hline female & $233.8 \pm 58.3$ & $286.4 \pm 73.6$ & $0.0008^{* *}$ \\
\hline \multicolumn{4}{|l|}{ Hemoglobin [g/dl] $(\mathrm{M} \pm \mathrm{SD})$} \\
\hline male & $16.0 \pm 2.1$ & $15.7 \pm 3.3$ & $0.3172^{\mathrm{a}}$ \\
\hline female & $13.2 \pm 0.8$ & $13.4 \pm 1.6$ & $0.3311^{\mathrm{a}}$ \\
\hline \multicolumn{4}{|l|}{ Hematocrit [\%] (M $\pm \mathrm{SD})$} \\
\hline male & $46.6 \pm 3.2$ & $46.0 \pm 4.1$ & $0.2103^{\mathrm{a}}$ \\
\hline female & $40.0 \pm 2.5$ & $40.6 \pm 4.6$ & $0.2675^{\mathrm{a}}$ \\
\hline \multicolumn{4}{|c|}{ Blood urea nitrogen $(\mathrm{BUN})[\mathrm{mg} / \mathrm{dl}](\mathrm{M} \pm \mathrm{SD})$} \\
\hline male & $13.8 \pm 3.7$ & $13.7 \pm 4.8$ & $0.4516^{\mathrm{a}}$ \\
\hline female & $13.1 \pm 3.5$ & $12.3 \pm 4.6$ & $0.2147^{\mathrm{a}}$ \\
\hline \multicolumn{4}{|l|}{ Creatinine $[\mathrm{mg} / \mathrm{dl}](\mathrm{M} \pm \mathrm{SD})$} \\
\hline male & $0.9 \pm 0.2$ & $1.1 \pm 0.4$ & $0.1280^{\mathrm{a}}$ \\
\hline female & $0.6 \pm 0.1$ & $0.8 \pm 0.2$ & $0.000^{* *}$ \\
\hline \multicolumn{4}{|c|}{ Alkaline phosphatase (ALP) [IU/l] $(\mathrm{M} \pm \mathrm{SD})$} \\
\hline male & $71.9 \pm 17.7$ & $81.4 \pm 23.7$ & $0.0088^{* *}$ \\
\hline female & $72.7 \pm 15.9$ & $83.5 \pm 16.7$ & $0.0287^{*}$ \\
\hline \multicolumn{4}{|c|}{ Aspartate amino transferase (AST) [IU/l] $(\mathrm{M} \pm \mathrm{SD})$} \\
\hline male & $21.9 \pm 5.5$ & $33.3 \pm 6.2$ & $0.0158^{*}$ \\
\hline female & $18.6 \pm 4.9$ & $21.1 \pm 5.2$ & $0.1297^{\mathrm{a}}$ \\
\hline \multicolumn{4}{|c|}{ Alanine amino transferase (ALT) [IU/l] $(\mathrm{M} \pm \mathrm{SD})$} \\
\hline male & $27.8 \pm 4.6$ & $37.0 \pm 7.8$ & $0.0231^{*}$ \\
\hline female & $18.6 \pm 6.0$ & $23.4 \pm 7.9$ & $0.1332^{\mathrm{a}}$ \\
\hline
\end{tabular}

$\mathrm{M}$ - mean; SD - standard deviation.

$* \mathrm{p}=0.05 ; * \mathrm{p}=0.001$.

${ }^{\text {a }}$ Did not reach statistical significance. 
Table 4. Hematologic and hepatic indices among smoking subjects unexposed and exposed to benzene, according to age group

\begin{tabular}{|c|c|c|c|}
\hline \multirow[b]{2}{*}{ Variable and age group } & \multicolumn{2}{|c|}{$\begin{array}{l}\text { Respondents } \\
(\mathrm{N}=791)\end{array}$} & \multirow[b]{2}{*}{$\mathrm{p}$} \\
\hline & $\begin{array}{c}\text { unexposed } \\
(\mathrm{N}=58 ; \\
<40 \text { years: } \mathrm{N}=25, \\
\geq 40 \text { years: } \mathrm{N}=33)\end{array}$ & $\begin{array}{c}\text { exposed } \\
(\mathrm{N}=733 \\
<40 \text { years: } \mathrm{N}=335, \\
\geq 40 \text { years: } \mathrm{N}=398)\end{array}$ & \\
\hline \multicolumn{4}{|l|}{$\mathrm{WBC}\left[\times 10^{3} / \mu \mathrm{l}\right](\mathrm{M} \pm \mathrm{SD})$} \\
\hline$<40$ years & $7.3 \pm 1.0$ & $8.0 \pm 1.9$ & $0.0395^{*}$ \\
\hline$\geq 40$ years & $7.2 \pm 1.6$ & $8.2 \pm 2.1$ & $0.0061^{* *}$ \\
\hline \multicolumn{4}{|l|}{ Platelets $\left[\times 10^{3} / \mu 1\right](\mathrm{M} \pm \mathrm{SD})$} \\
\hline$<40$ years & $227.2 \pm 45.4$ & $266.6 \pm 62.8$ & $0.0000^{* *}$ \\
\hline$\geq 40$ years & $232.0 \pm 34.1$ & $280.2 \pm 66.9$ & $0.0000^{* *}$ \\
\hline \multicolumn{4}{|l|}{ Hemoglobin $[\mathrm{g} / \mathrm{dl}](\mathrm{M} \pm \mathrm{SD})$} \\
\hline$<40$ years & $14.8 \pm 1.3$ & $14.9 \pm 1.5$ & $0.3707^{\mathrm{a}}$ \\
\hline$\geq 40$ years & $14.4 \pm 1.4$ & $14.5 \pm 1.7$ & $0.3414^{\mathrm{a}}$ \\
\hline \multicolumn{4}{|l|}{ Hematocrit $[\%](\mathrm{M} \pm \mathrm{SD})$} \\
\hline$<40$ years & $42.7 \pm 2.8$ & $43.0 \pm 4.4$ & $0.3707^{\mathrm{a}}$ \\
\hline$\geq 40$ years & $43.0 \pm 3.8$ & $43.3 \pm 4.5$ & $0.3909^{\mathrm{a}}$ \\
\hline \multicolumn{4}{|c|}{ Blood urea nitrogen $(\mathrm{BUN})[\mathrm{mg} / \mathrm{dl}](\mathrm{M} \pm \mathrm{SD})$} \\
\hline$<40$ years & $12.8 \pm 2.8$ & $13.0 \pm 3.1$ & $0.2669^{\mathrm{a}}$ \\
\hline$\geq 40$ years & $13.2 \pm 2.9$ & $13.5 \pm 4.2$ & $0.4396^{\mathrm{a}}$ \\
\hline \multicolumn{4}{|l|}{ Creatinine $[\mathrm{mg} / \mathrm{dl}](\mathrm{M} \pm \mathrm{SD})$} \\
\hline$<40$ years & $0.8 \pm 0.2$ & $1.0 \pm 0.2$ & $0.0021^{* *}$ \\
\hline$\geq 40$ years & $0.8 \pm 0.2$ & $1.0 \pm 0.3$ & $0.0000^{* *}$ \\
\hline \multicolumn{4}{|c|}{ Alkaline phosphatase (ALP) [IU/l] $(\mathrm{M} \pm \mathrm{SD})$} \\
\hline$<40$ years & $70.8 \pm 7.5$ & $80.6 \pm 9.6$ & $0.0189^{*}$ \\
\hline$\geq 40$ years & $72.6 \pm 8.6$ & $89.4 \pm 12.2$ & $0.0002 * *$ \\
\hline \multicolumn{4}{|c|}{ Aspartate amino transferase (AST) $[\mathrm{IU} / \mathrm{l}](\mathrm{M} \pm \mathrm{SD})$} \\
\hline$<40$ years & $19.7 \pm 4.5$ & $24.2 \pm 6.7$ & $0.0129^{*}$ \\
\hline$\geq 40$ years & $21.0 \pm 5.1$ & $35.6 \pm 6.8$ & $0.0126^{*}$ \\
\hline \multicolumn{4}{|c|}{ Alanine amino transferase (ALT) [IU/l] $(\mathrm{M} \pm \mathrm{SD})$} \\
\hline$<40$ years & $19.0 \pm 6.0$ & $31.0 \pm 6.4$ & $0.0006^{* *}$ \\
\hline$\geq 40$ years & $22.1 \pm 4.7$ & $40.0 \pm 7.6$ & $0.0099 * *$ \\
\hline
\end{tabular}

M - mean; SD - standard deviation.

$* \mathrm{p}=0.05 ;{ }^{* *} \mathrm{p}=0.001$.

${ }^{a}$ Did not reach statistical significance. 
differences in hematologic and hepatic markers between the exposed and unexposed smoking subjects among the 2 age groups.

Regardless of their age, benzene-exposed smoking subjects had significantly higher levels of the mean WBC counts and platelet counts as compared with their matched unexposed age-groups. Conversely, the mean hemoglobin, hematocrit, and BUN levels remained statistically similar between the benzene-exposed and unexposed subjects regardless of the age-group. Compared with those unexposed subjects, benzene-exposed subjects had significantly higher levels of serum creatinine in both age groups. Similarly, significantly higher levels of hepatic enzymes (ALP, AST and ALT) were observed in the benzene-exposed subjects as compared with those unexposed subjects, regardless of age (Table 4).

\section{DISCUSSION}

Benzene is a volatile organic solvent and is known as one of the predominant toxic air pollutants in the environment. Benzene has long been known as a carcinogen of human blood components. In addition, benzene exposure may cause non-carcinogenic effects including hematologic, hepatic, neurologic, renal, and immunologic dysfunctions. However, the precise mechanism of the toxic effects of the benzene exposure is not fully understood. Despite the growing knowledge regarding the detrimental effects of benzene exposure, there have been no systematic investigations assessing its adverse health effects that may help in early detection of pathological alterations caused by benzene exposure.

Since tobacco smoking has a higher body burden of benzene [1], it is important to determine the health consequences of benzene exposure resulting from the prolonged BP's flaring incident among smoking residents. Therefore, we conducted this study assessing the alterations in the hematological and hepatic functions among smoking subjects following their exposure to benzene from the BP's prolonged flaring incident [23]. More specifically, in this study, we evaluated and compared the hematological and hepatic functions among benzene-exposed smoking subjects vs. unexposed smoking subjects. To the best of our knowledge this is the first study that has assessed the changes in the hematological and hepatic functions associated with benzene exposure resulting from the BP's prolonged flaring incident among smoking residents.

The findings of this study indicate that benzene exposure resulted in significant alterations in the hematological and hepatic functions among smoking subjects. More specifically, benzene-exposed smoking subjects had significant increase in their mean WBC and platelets counts as compared with those unexposed smoking subjects. Hemoglobin and hematocrit levels remained similar between the 2 groups. Similarly, no changes were observed in the mean levels of BUN and creatinine between the exposed and unexposed groups. Although several earlier studies had assessed the adverse health effects of benzene exposure [30-32], those study populations had been mixed with both smoking and nonsmoking subjects.

Recently, we have reported significant alterations in the hematological and hepatic profiles among nonsmoking residents following their exposure to benzene due to the BP's flaring incident [25]. Together, these studies further indicate that subjects exposed to benzene experience significant alterations in their hematological and hepatic functions regardless of their smoking status or history. It is well established that assessment of enzymes such as ALP, AST and ALT in the serum routinely measured for liver functions evaluation [33]. Since benzene exposure is known to affect hepatic functions, in this study we have assessed the changes in ALP, AST, and ALT levels in the serum of benzene-exposed smoking subjects and compared them with those of unexposed smoking subjects. Our findings show that the serum levels of ALP, AST, and ALT increased significantly in the benzene-exposed subjects as compared with those unexposed subjects. 
The elevated levels of these enzymes found in this study are consistent with the other published studies where increased liver enzymes have been reported for adult subjects who have been exposed to benzene or petroleum products and organic solvents [34-38]. Since benzene exposure causes dysfunction of hepatic tissues, it may lead to the liberation of increased levels of hepatic enzymes into the circulation. Alternatively, benzene exposure may cause hepatocellular injury resulting in the activation of liver cells leading to the overproduction of hepatic enzymes. Additional studies, however, are needed to evaluate the precise mechanisms of benzene induced hepatic toxicity among smoking subjects.

To understand the health consequences of the benzene exposure among smoking subjects, we further assessed and compared the hematological and hepatic outcomes by their gender as well as by their age ( $<40$ years old and $\geq 40$ years old). The findings indicate that benzene-exposed smoking subjects had significantly altered hematological and hepatic functions as compared with the unexposed nonsmoking subjects regardless of their gender or age.

Several limitations were taken into consideration when interpreting our study findings. First this study has utilized a cross-sectional design for the evaluation; therefore, the findings should be interpreted with caution. Generally, a cross-sectional study design only allows for the hypothesis for further investigation, and not causality to be investigated. It is difficult to draw a causality using such a study design because the clinical outcomes were measured at one point in time after an event. Thus, the causality may only be an assumption.

Another important limitation of this study has been the lack of baseline data of the study subjects prior to their benzene exposure for a comparison. Since it is a retrospective study, the procedures used for evaluation have not followed a predefined protocol. Although, prospective randomized studies are necessary to validate current findings, planning such randomized studies to assess the adverse health effects from a disaster similar to the BP incident is not practicable.

Regardless of this study's limitations, the findings suggest that smoking subjects exposed to benzene have potential health risks including alterations in hematological, hepatic and other organ functions. Several previously published studies had shown that benzene exposure increased the risk of carcinogenesis including hematological and lung cancers. Yin et al. [39] reported an increased risk of leukemia, lymphoma and lung cancers among benzene-exposed workers as compared to unexposed workers in China. Therefore, periodic checkups and routine blood tests are necessary to detect any long-term toxic effects, particularly, monitoring the risk of developing secondary malignancies for the benzene-exposed subjects. Periodic health checkups include pulmonary, cardiac, neurologic, and other organ function tests should be performed to monitor the long-term health consequences for benzene-exposed subjects regardless of their gender, age, and smoking status. Thus, longitudinal and mechanistic studies are required to explore the importance and nature of the human health effects of benzene exposure.

\section{CONCLUSIONS}

In summary, the results of this study suggest that regardless of subjects' smoking history, benzene exposure from the BP refinery flaring incident has an increased risk of altering both the hematological and hepatic functions for those residents living in the affected area. Among the hematological indices, WBC counts and platelet counts have been found to be increased in the benzene-exposed subjects as compared with the unexposed subjects.

Similarly, the serum levels of hepatic enzymes such as ALP, AST, and ALT were increased significantly in the case of the benzene-exposed subjects indicating hepatic injury in this population. However, further studies are needed to understand the other potential detrimental long-term human health effects of the benzene exposure from the flaring incident at the BP refinery facility in Texas City, USA. 


\section{REFERENCES}

1. Wallace L. Environmental exposure to benzene: An update. Environ Health Perspect. 1996 Dec;104 Suppl 6:1129-36, https://doi.org/10.1289/ehp.961041129.

2. Khalade A, Jaakkola MS, Pukkala E, Jaakkola JJ. Exposure to benzene at work and the risk of leukemia: A systematic review and meta-analysis. Environ Health. 2010;9:31, https:// doi.org/10.1186/1476-069X-9-31.

3. Smith MT. Advances in understanding benzene health effects and susceptibility. Annu Rev Public Health. 2010;31:133-48, https://doi.org/10.1146/annurev.publhealth.012809.103646.

4. Costantini AS, Benvenuti A, Vineis P, Kriebel D, Tumino R, Ramazzotti V, et al. Risk of leukemia and multiple myeloma associated with exposure to benzene and other organic solvents: Evidence from the Italian Multicenter Case-control study. Am J Ind Med. 2008 Nov;51(11):803-11, https://doi. org/10.1002/ajim.20592.

5. Snyder R. Overview of the toxicology of benzene. J Toxicol Environ Health A. 2000 Nov;61(5-6):339-46, https:/doi. org/10.1080/00984100050166334.

6. Marchetti F, Eskenazi B, Weldon RH, Li G, Zhang L, Rappaport SM, et al. Occupational exposure to benzene and chromosomal structural aberrations in the sperm of Chinese men. Environ Health Perspect. 2012 Feb;120(2):229-34, https://doi.org/10.1289/ehp.1103921.

7. Dundarz MR, Turkbay T, Akay C, Sarici SU, Aydin A, Denli M, et al. Antioxidant enzymes and lipid peroxidation in adolescents with inhalant abuse. Turk J Pediatr. 2003 Jan$\operatorname{Mar} ; 45(1): 43-5$.

8. Dere E, Ari F. Effect of benzene on liver functions in rats (Rattus norvegicus). Environ Monit Assess. 2009 Jul;154 (1-4):23-7, https://doi.org/10.1007/s10661-008-0374-7.

9. Kotseva K, Popov T. Study of the cardiovascular effects of occupational exposure to organic solvents. Int Arch Occup Environ Health. 1998 Sep;71 Suppl:S87-91.

10. Baslo A, Aksoy M. Neurological abnormalities in chronic benzene poisoning. A study of six patients with aplastic anemia and two with preleukemia. Environ Res.
1982 Apr;27(2):457-65, https://doi.org/10.1016/0013-9351 (82)90100-1.

11. Mandiracioglu A, Akgur S, Kocabiyik N, Sener U. Evaluation of neuropsychological symptoms and exposure to benzene, toluene and xylene among two different furniture worker groups in Izmir. Toxicol Ind Health. 2011 Oct;27(9):802-9, https://doi.org/10.1177/0748233711399309.

12. Vinceti M, Rothman KJ, Crespi CM, Sterni A, Cherubini A, Guerra $\mathrm{L}$, et al. Leukemia risk in children exposed to benzene and PM10 from vehicular traffic: A case-control study in an Italian population. Eur J Epidemiol. 2012 Oct;27(10):78190, https://doi.org/10.1007/s10654-012-9727-1.

13. Whitworth KW, Symanski E, Coker AL. Childhood lymphohematopoietic cancer incidence and hazardous air pollutants in southeast Texas, 1995-2004. Environ Health Perspect. 2008 Nov;116(11):1576-80, https://doi.org/10.1289/ ehp.11593.

14. Kim S, Vermeulen R, Waidyanatha S, Johnson BA, Lan Q, Smith MT, et al. Modeling human metabolism of benzene following occupational and environmental exposures. Cancer Epidemiol Biomarkers Prev. 2006 Nov;15(11):2246-52, https://doi.org/10.1158/1055-9965.EPI-06-0262.

15. Renaud HJ, Rutter A, Winn LM. Assessment of xenobiotic biotransformation including reactive oxygen species generation in the embryo using benzene as an example. Methods Mol Biol. 2012;889:253-63, https://doi.org/10.1007/978-161779-867-2_15.

16. Krieg EF, Jr., Mathias PI, Toennis CA, Clark JC, Marlow KL, B'Hymer C, et al. Detection of DNA damage in workers exposed to JP-8 jet fuel. Mutat Res. 2012 Sep 18;747(2): 218-27, https://doi.org/10.1016/j.mrgentox.2012.05.005.

17. Wang L, He X, Bi Y, Ma Q. Stem cell and benzene-induced malignancy and hematotoxicity. Chem Res Toxicol. $2012 \mathrm{Jul}$ 16;25(7):1303-15, https://doi.org/10.1021/tx3001169.

18. Ermolina EV, Stadnikov AA, Smoliagin AI. [Morphological features of the organs of the immune system in conditions of exposure to chromium and benzene]. Gig Sanit. 2012 MayJun;(3):69-71. Russian. 
19. Veraldi A, Costantini AS, Bolejack V, Miligi L, Vineis P, van Loveren $H$. Immunotoxic effects of chemicals: A matrix for occupational and environmental epidemiological studies. Am J Ind Med. 2006 Dec;49(12):1046-55, https://doi. org/10.1002/ajim.20364.

20. Evans L. BP's 40-Day Emissions Event [Internet]. New York: ProPublica; 2010 [cited 2014 June 2]. Available from: http://www.propublica.org/documents/item/bps-40-dayemissions-event.

21. Knutson R. BP Texas refinery had huge toxic release just before gulf blowout [Internet]. New York: ProPublica; 2010 [cited 2014 June 2]. Available from: http://www.propublica. org/article/bp-texas-refinery-had-huge-toxic-release-justbefore-gulf-blowout.

22. Evans L. Texas Commission on Environmental Quality Investigation report. Emissions event (Incident No. 138052). Review on British Petrolium products, North America (Investigation No. 824714). The Commission; 2010.

23. D'Andrea MA, Singh O, Reddy GK. Health consequences of involuntary exposure to benzene following a flaring incident at British Petroleum refinery in Texas City. Am J Disaster Med. 2013 Summer;8(3):169-79, https://doi.org/10.5055/ ajdm.2013.0124.

24. D'Andrea MA, Reddy GK. Health effects of benzene exposure among children following a flaring incident at the British Petroleum Refinery in Texas City. Pediatr Hematol Oncol. 2014 Feb;31(1):1-10, https://doi.org/10.3109/0888001 8.2013.831511.

25. D'Andrea MA, Reddy GK. Hematological and hepatic alterations in nonsmoking residents exposed to benzene following a flaring incident at the British petroleum plant in Texas City. Environ Health. 2014;13(12):115, https://doi. org/10.1186/1476-069X-13-115.

26. D'Andrea MA, Reddy GK. Adverse health effects of benzene exposure among children following a flaring incident at the British Petroleum Refinery in Texas City. Clin Pediatr (Phila). 2016;55(3):219-27, https://doi.org/10.1177/ 0009922815594358.
27. D'Andrea MA, Reddy GK. Detrimental health effects of benzene exposure among adults after a flaring disaster at the BP refinery plant in Texas City. Disaster Med Public Health Prep. 2016;10(2):233-9, https://doi.org/10.1017/dmp. 2015.160 .

28. D'Andrea MA, Reddy GK. Illness symptoms experienced by children exposed to benzene after a flaring incident at the BP refinery facility in Texas City. Clin Pediatr (Phila). 2016;55(12):1143-51, https://doi.org/10.1177/00099 22816641463.

29. Agency for Toxic Substances and Disease Registry. Toxicological profile for benzene [Internet]. Atlanta: The Agency; 2007 [cited 2014 June 2]. Available from: http://www.atsdr. cdc.gov/toxprofiles/tp3.pdf.

30. Liu C-S, Tsai J-H, Kuo S-W. Comparison of complete blood counts and urinary benzene metabolites after exposure to benzene. Mid Taiwan J Med. 2000;5:235-42.

31. Ray MR, Roychoudhury S, Mukherjee S, Lahiri T. Occupational benzene exposure from vehicular sources in India and its effect on hematology, lymphocyte subsets and platelet P-selectin expression. Toxicol Ind Health. 2007 Apr;23(3): 167-75, https://doi.org/10.1177/0748233707080907.

32. Avogbe PH, Ayi-Fanou L, Cachon B, Chabi N, Debende A, Dewaele D, et al. Hematological changes among Beninese motor-bike taxi drivers exposed to benzene by urban air pollution. Afr J Environ Sci Technol. 2011;5:464-72.

33. Innerfield F. Enzymes in clinical chemistry. New York.: McGraw Hill Publications; 1960.

34. Chang WJ, Joe KT, Park HY, Jeong JD, Lee DH. The relationship of liver function tests to mixed exposure to lead and organic solvents. Ann Occup Environ Med. 2013;25(1):5, https://doi.org/10.1186/2052-4374-25-5.

35. Mohammadi S, Mehrparvar A, Labbafinejad Y, Attarchi MS. The effect of exposure to a mixture of organic solvents on liver enzymes in an auto manufacturing plant. J Public Health. 2010;18:553-7, https://doi.org/10.1007/s10389-010-0340-z.

36. Perez CA, Bosia JD, Cantore MS, Chiera A, Cocozzella DR, Adrover RE, et al. [Liver damage in workers exposed 
to hydrocarbons]. Gastroenterol Hepatol. 2006 Jun-Jul; 29(6):334-7, https://doi.org/10.1157/13089716. Spanish.

37. Tomei F, Giuntoli P, Biagi M, Baccolo TP, Tomao E, Rosati MV. Liver damage among shoe repairers. Am J Ind Med. 1999 Nov;36(5):541-7, https://doi.org/10.1002/(SICI) 1097-0274(199911)36:5<541::AID-AJIM6>3.0.CO;2-4.

38. Fernández-D'Pool J, Oroño-Osorio A. Liver function of workers occupationally exposed to mixed organic solvents in a petrochemical. Invest Clin. 2001;42:87-106.
39. Yin SN, Hayes RB, Linet MS, Li GL, Dosemeci M, Travis $\mathrm{LB}$, et al. An expanded cohort study of cancer among benzene-exposed workers in China. Benzene Study Group. Environ Health Perspect. 1996 Dec;104 Suppl 6:1339-41, https://doi.org/10.1289/ehp.961041339.

This work is available in Open Access model and licensed under a Creative Commons Attribution-NonCommercial 3.0 Poland License - http://creativecommons.org/ licenses/by-nc/3.0/pl/deed.en. 